\begin{tabular}{|c|c|c|}
\hline 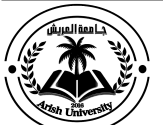 & $\begin{array}{l}\text { SCREENED BY SINAI Journal of Applied Sciences } \\
\text { iThenticate }\end{array}$ & $\overline{\overline{\text { SRU-EGYPT }}}$ \\
\hline
\end{tabular}

\title{
EFFECT OF IRRIGATION LEVELS ON GROWTH AND YIELD OF TOMATO UNDER EL-ARISH REGION CONDITIONS
}

\author{
Safaa A.M. El-Labad ${ }^{1 *}$, M.I. Mahmoud ${ }^{1}$, S.A. Abo El-Kasem ${ }^{2}$ and A.I. El-Kassas ${ }^{1}$ \\ 1. Dept. Plant Prod., Fac. Environ. Agric. Sci., Arish Univ., Egypt. \\ 2. Dept. Self-Pollinated Veg. Res., Inst. Hort. Res., Cent. Agric. Res., Egypt.
}

\begin{abstract}
Field experiments were carried out in summer season of 2017 and 2018 at the Experimental Farm, Faculty of Environmental Agricultural Sciences, Arish University, North Sinai to study the effect of four irrigation levels $(100 \%, 80 \%, 60 \%$ and $40 \%$ of irrigation requirements) on growth and yield of tomato. Seeds of " $\mathrm{GS}_{12} \mathrm{~F}_{1}$ " hybrid were sown in plastic speeding trays on $14^{\text {th }}$ March and transplanting was carried out on $23^{\text {rd }}$ April. Plants were irrigated using drip irrigation system, the distance between dripper lines centers was $1.2 \mathrm{~m}$. The plot area was $14.4 \mathrm{~m}^{2}$ (12 m length and $1.2 \mathrm{~m}$ width), the distance between the plants in the same row was $50 \mathrm{~cm}$, planting density was $1.67 \mathrm{plant} / \mathrm{m}^{2}$. The highest values of all studied vegetative growth traits, fresh and dry weights, and contents of chlorophyll a, chlorophyll b, and carotenoids were recorded with application of $80 \%$ followed by $100 \%$ irrigation levels. The highest value for each of grade a, grade $b$, and total marketable fruit yield per fad., were recorded with the $80 \%$ irrigation level in both seasons. The highest unmarketable yield was recorded with the use of the irrigation level of $60 \%$, while the lowest values were recorded with application of $100 \%$ or $80 \%$ irrigation level.
\end{abstract}

Key words: Irrigation, tomato, requirements, levels, water use, efficiency.

\section{INTRODUCTION}

Increasing water scarcity will observe less increase in irrigated land availability for food production than in the past. While irrigation can benefit yields and enhance water use efficiency (WUE) in water limited environments, the potential for full irrigation is decreasing, so, irrigated agriculture is to improve WUE and sustainable water use for agriculture. Salt stress in soil or water is one of the major stresses especially in arid and semi-arid regions and can severely limit plant growth and productivity (Allakhverdiev et al., 2000; Koca et al., 2007). Ismail et al. (2007) found that increasing water supply increased the root development and root biomass. Al-Omran et al. (2010) studied the effects of water quality, irrigation system, irrigation rates and type of amendment on the yield and quality of tomato plants. They found that at a high irrigation rate $\left(61 \mathrm{~h}^{-1}\right)$, tomato yields were higher and decreased significantly at a low irrigation rate $\left(21 \mathrm{~h}^{-1}\right)$ in both seasons. Low quality of irrigation water significantly increased fruit $\mathrm{pH}$ '.

Berihun (2011) studied the effect of mulch and amount of water on the yield of tomato under drip irrigation system and to assess the potential of deficit irrigation to improve the economic efficiency of tomato production at North Western Ethiopia. He found that amount of water significantly affected the number of fruits per plant and average weight of fruits, marketable and total fruit yield/ha". Ezekiel (2013) studied the effect of water regime and mulching on the growth and yield of tomato in Nigeria to

\footnotetext{
* Corresponding author: Tel.: +201090854071

E-mail address: safaaahmed497@gmail.com
} 
evaluate water management options on the performance of tomato. They found that water regime of $0.3,0.4$ and 0.5 litre/day/ plant gave the following yield 112.3, 140.01 and $154.34 \mathrm{~g} /$ pot. Sibomana et al. (2013) subjected tomato Money Maker $c v$. to four soil moistures these hold levels of $100 \%, 80 \%, 60 \%$ and $40 \%$ Field capacity. They reported that severe water stress $(40 \%$ of FC resulted in significant decreases in chlorophyll content and chlorophyll concentration by $32 \%$ compared to the control).

Biswas et al. (2015) studied the effects of drip irrigation and mulches on yield, water-use efficiency and economic return of tomato plant at different combinations of three drip irrigation levels (100, 75 and 50\% of crop water requirement) and two mulches (black polyethylene sheet and paddy straw). They found that the yield and yieldcontributing characters in the mulched treatments for all levels of irrigation were significantly higher compared to those in the un-mulched treatments. The yield of tomato increased with increasing amount of irrigation water in un-mulched treatment. The trend was reversed when drip irrigation was coupled with mulches."

Ragab et al. (2018) studied the alleviating of water stress for tomato plants cultivated in a sandy soil and were exposed to deficit irrigation (DI) treatments; 100\%, 85\%, 70\% and $55 \%$ of Evapotranspiration maximum (ETm), using two irrigation systems (surface drip irrigation (SDI) and subsurface drip irrigation (SSDI), Results clearly indicated that the full irrigation treatment $100 \%$ ETm produced the highest significant values of total leaves area and fresh and dry weights of tomato leaf per plant. Increasing the irrigation water from 55\% ETm to $100 \%$ ETm produced a good vegetable growth of tomato plants which affected positively on the flowering (number of flowers per plant) and fruit yield. Decreasing irrigation water significantly increased TSS, total sugars and ascorbic acid content in tomato fruits, where $55 \%$ ETm treatment produced the highest significant values.

Arish soil is characterized as sandy soil, generally, has low moisture holding capacity, single grain structure, susceptibility to erosion and has low levels of nutrients and microorganisms. Irrigation in this area depends on wells of underground water with low quality (high saline water). So, this study aimed to use the prober irrigation level for tomato production which save water under such conditions.

\section{MATERIALS AND METHODS}

Field experiments were carried out for two consecutive growing summer seasons of 2017 and 2018 at The Experimental Farm of Environmental Agricultural Sciences Faculty, Arish University, North Sinai to study the effect of four irrigation levels $(100 \%, 80 \%, 60 \%$ and $40 \%$ of tomato plant requirements from water during all plant growth stages) on growth and yield of tomato. Seeds of " $\mathrm{Gs}_{12} \mathrm{~F}_{1}$ " phybrid were sown in plastic seedling trays on $14^{\text {th }}$ March and transplanting was carried out on the $23^{\text {rd }}$ April.

Plants were irrigated using drip irrigation system, the distance between the plants in the same row was $50 \mathrm{~cm}$, while the distance between dripper lines centers was $1.2 \mathrm{~m}$. The plot area was $14.4 \mathrm{~m}^{2}$ (12 m length and $1.2 \mathrm{~m}$ width), planting density was 1.67 plant $/ \mathrm{m}^{2}$. Four irrigation levels were used. Chemical analyses of irrigation water as well as physical and chemical analyses of experimental soil are shown in Tables 1 and 2. Soil parameters determined before conducting the experiments were particle size distribution (Pipper, 1950), total carbonate (Jackson, 1967), and soil $\mathrm{pH}$ value was determined in 1: 2.5 soil water suspension. The soil water extract for 1:5 soil water ratio was chemically analyzed for electrical conductivity (EC) according to Richard (1954) and Jackson (1967). 
SINAI Journal of Applied Sciences (ISSN: 2314-6079), Vol. (8), Is. (1), Apr. 2019

Table (1): Chemical properties of irrigation water.

\begin{tabular}{|c|c|c|c|c|c|c|c|c|c|}
\hline \multirow[t]{3}{*}{$\mathbf{p H}$} & \multirow{3}{*}{$\begin{array}{c}\mathrm{EC} \\
\mathrm{dSm}^{-1}\end{array}$} & \multicolumn{8}{|c|}{ Soluble ions $\left(\mathrm{me} \mathrm{l}^{-1}\right)$} \\
\hline & & \multicolumn{4}{|c|}{ Cations } & \multicolumn{4}{|c|}{ Anions } \\
\hline & & $\mathrm{Ca}^{++}$ & $\mathrm{Mg}^{++}$ & $\mathrm{Na}^{+}$ & $\mathbf{K}^{+}$ & $\mathrm{Cl}^{-}$ & $\mathrm{HCO}_{3}{ }^{-}$ & $\mathrm{CO}_{3}^{--}$ & $\mathrm{SO}_{4}{ }^{--}$ \\
\hline \multicolumn{10}{|c|}{ First season (2017) } \\
\hline 7.55 & 5.56 & 20.50 & 16.80 & 18.50 & 0.24 & 45.92 & 2.90 & - & 7.58 \\
\hline \multicolumn{10}{|c|}{ Second season (2018) } \\
\hline 7.60 & 5.71 & 21.00 & 17.00 & 18.80 & 0.25 & 46.77 & 2.99 & - & 7.29 \\
\hline
\end{tabular}

Table (2): Physical and chemical properties of investigated soil profile of cultivated area.

\begin{tabular}{|c|c|c|}
\hline \multicolumn{3}{|c|}{ Particles size distribution (\%) } \\
\hline & First season (2017) & second season (2018) \\
\hline Coarse sand (\%) & 58.3 & 59.5 \\
\hline Fine sand (\%) & 19.8 & 19.3 \\
\hline Silt (\%) & 12.9 & 12.0 \\
\hline Clay $(\%)$ & 10.0 & 10.1 \\
\hline Soil texture & Sandy loam & Sandy loam \\
\hline Bulk density $\left(\mathrm{Mgm}^{-1}\right)$ & 1662 & 1661 \\
\hline \multicolumn{3}{|c|}{ Chemical properties (Soluble ions (in 1:5 soil water extract) } \\
\hline $\mathrm{Ca}^{+}\left(\mathrm{mel}^{-1}\right)$ & 3.90 & 3.90 \\
\hline $\operatorname{Mg}^{+}\left(\mathrm{mel}^{-1}\right)$ & 3.42 & 3.43 \\
\hline $\mathrm{Na}^{+}\left(\mathrm{mle}^{-1}\right)$ & 2.54 & 2.55 \\
\hline $\mathbf{K}^{+}\left(\mathbf{m e l}^{-1}\right)$ & 0.34 & 0.32 \\
\hline $\mathrm{CO}_{3}^{-}\left(\mathrm{mle}^{-1}\right)$ & - & - \\
\hline $\mathrm{HCO}_{3}^{-}\left(\mathrm{mel}^{-1}\right)$ & 4.30 & 4.40 \\
\hline $\mathrm{Cl}^{-}\left(\mathrm{mel}^{-1}\right)$ & 4.40 & 4.35 \\
\hline $\mathrm{SO}_{4}\left(\mathrm{mel}^{-1}\right)$ & 1.50 & 1.45 \\
\hline $\mathbf{E C}\left(\mathrm{dSml}^{-1}\right)$ & 1.04 & 1.02 \\
\hline pH (in1:2.5 Soil water suspension extract) & 8.10 & 8.13 \\
\hline Organic matter (\%) & 0.153 & 0.171 \\
\hline $\mathrm{CaCO}_{3}(\%)$ & 22.43 & 22.48 \\
\hline
\end{tabular}


Irrigation treatments started after three weeks from transplanting. Data recorded were as follows: Three plants were randomly chosen for determining the following parameters: vegetative growth; fresh and dry weight of plant; leaves content of photosynthetic pigments (all at 30 and 60 days after transplanting), fruit yield and its component and fruit quality.

Treatments were randomly distributed in a complete randomized block design in three replications. Irrigation water levels were randomly distributed in main plots. The normal agricultural practices were carried out as commonly followed in ElArish region. The obtained data were subjected to statistical analysis of variance according to Snedecor and Cochran (1980), and means separation was done according to Duncan (1955). M. Stat C programmer was used for analysis.

\section{RESULTS AND DISCUSSION}

\section{Effect of Irrigation Levels}

\section{Vegetative growth}

Data in Table 3 show significant effects on all vegetative growth traits, except plant height in the first season at 30 days after transplanting, leaf area per plant in both seasons, number of leaves per plant in both seasons, and number of branches in the second season at 30 days after transplanting. The highest values of most studied traits were recorded with applying the irrigation level of $80 \%$ followed by $100 \%$.

These results may be due to that drip irrigation had higher efficiency of providing plants with their requirements of water and nutrients. Many researchers came to similar results, Sibomana et al. (2013) found that' Severe water stress $(40 \%$ of FC) reduced the tomato plant height by $24 \%$, and stem diameter by 18\%'. Also, Ragab et al. (2018) indicated that 'increasing the irrigation water from $55 \%$ ETm to $100 \%$ ETm produced a good vegetable growth of tomato plants which affected positively on the flowering and fruit yield, full irrigation treatment $(100 \%$ ETm $)$ produced the highest significant values of total leaf area'.

\section{Fresh weight}

Data in Table 4 show significant effects for irrigation levels on all fresh weight traits in both seasons. The highest values of root fresh weight were recorded with application of $100 \%$ irrigation level in both sampling dates in both seasons, the highest values of stem fresh weight were recorded with $80 \%$ irrigation level at the first sampling date and with $100 \%$ irrigation level at the second sampling date in both seasons. Concerning leaf fresh weight, the highest values was recorded with application of 100 or $80 \%$ irrigation level without significant difference between them at both sampling dates in both seasons.

Regarding total plant fresh weight, the highest total fresh weight was recorded with application of $100 \%$ or 80 irrigation level at both sampling dates in both seasons. These results may be due to that plants had their requirements from water and nutrients with application of $100 \%$ or $80 \%$ levels of irrigation using drip irrigation system. In this concern, Ragab et al. (2018) reported that 'the full irrigation treatment (100\%) Etm produced the highest significant value for each of total leaf area and fresh and dry weights of tomato leaves per plant'.

\section{Dry weight}

Data in Table 5 show significant effects due to the application of irrigation levels on all dry weight traits in both seasons, except, stem dry weight at 30 days after transplanting in the first season. The highest value for each of dry weight of roots, stem and total plant dry weight followed the same trend of fresh weight in Table 4, while the highest leaves fresh weight was recorded with application of $80 \%$ irrigation level at the first sampling date and with application of 
$100 \%$ irrigation level at the second sampling date in both seasons. These results might be due to good vegetative growth (Table 4) which reflected higher photosynthetic process that led to higher dry matter accumulation. These results are in harmony with the findings of Ragab et al. (2018) who reported that 'the full irrigation treatment (100\% Etm) produced the highest significant value for each of total leaf area and fresh and dry weights of tomato leaves per plant'.

\section{Leaves chlorophyll and carotenoids content}

Data in Table 6 show significant effects for irrigation levels on all studied traits in both seasons, except, content of chlorophyll $\mathrm{a}$ at 30 days after transplanting in the second season, and content of chlorophyll b at the first sampling date in the first season. The highest contents of chlorophyll a was recorded with application of $80 \%$ or $100 \%$ irrigation level. The highest content of chlorophyll b was recorded with application of $100 \%, 80 \%$ or $60 \%$ irrigation level in the first sampling date, while its highest content at the second sampling date was recorded with application of $80 \%$ irrigation level in both seasons. The highest content of carotenoids was recorded with application of $100 \%, 80 \%$ or $60 \%$ irrigation level in the first sampling date, while its highest content at the second sampling date was recorded with application of $80 \%$ irrigation level in both seasons. These results may be due to the effect of irrigation treatments on vegetative growth (Table 4) where higher vegetative growth especially leaves area reflected higher photosynthetic prosses.

\section{Yield and its components}

Data in Table 7 show significant effects for irrigation levels on all marketable fruit yield and its component traits in both seasons, except weight of grade b fruits in both seasons. Concerning mean weight of grade (a) fruit, the heaviest fruits were obtained due to application of $100 \%$ irrigation level in both seasons. The irrigation level of $80 \%$ resulted in the highest value of number of fruits and fruit weight of grade a, grade b, and total fruit yield, except number of fruits of grade $b$ in both seasons. These results are on the same line of results of Biswas et al. (2015) who found that the yield of tomato increased with increasing amount of irrigation water in un-mulched treatment. The trend was reversed when drip irrigation was coupled with mulches. Concerning unmarketable yield data in Table 8 show significant effects for irrigation treatments on studied traits in both seasons. The highest number of unmarketable fruits was recorded with the use of the lowest irrigation levels (60 and $40 \%$ irrigation levels), while the lowest values were recorded with application of $100 \%$ or $80 \%$ irrigation level. The highest unmarketable fruit yield was recorded with application of $60 \%$ irrigation level in both seasons.

\section{Fruit quality}

Data in Table 9 indicate significant effects of irrigation levels on all fruit quality traits, except, fruit diameter and fruit shape in both seasons and fruit $\mathrm{pH}$ in the second season. The highest value of fruit length was recorded with application of $80 \%$ level in both seasons. The highest pericarp thickness was with $100 \%$ irrigation level in both seasons, the highest value of fruit $\mathrm{TSS} \%$ was obtained due to $40 \%$ followed by $60 \%$ irrigation level in both seasons.Concerning content of Vitam. C and fruit $\mathrm{pH}$, the highest records were with application of $80 \%$ irrigation level in both seasons. These results are in agreement with those of Ragab et al. (2018) who reported that decreasing irrigation water significantly increased $\mathrm{TSS} \%$, total sugars and ascorbic acid content in tomato fruits, where $55 \%$ ETm treatment produced the highest significant values. 
Table (3): Effect of irrigation water levels on vegetative growth of tomato plant in 2017 and 2018 seasons.

\begin{tabular}{|c|c|c|c|c|c|c|c|c|c|c|}
\hline \multirow{3}{*}{$\begin{array}{l}\text { Parameter } \\
\text { Irrigation } \\
\text { water levels } \\
\text { (requirements) }\end{array}$} & \multicolumn{2}{|c|}{$\begin{array}{l}\begin{array}{c}\text { Plant height } \\
(\mathrm{cm})\end{array} \\
\end{array}$} & \multicolumn{2}{|c|}{$\begin{array}{c}\begin{array}{c}\text { Root length } \\
(\mathrm{cm})\end{array} \\
\end{array}$} & \multicolumn{2}{|c|}{$\begin{array}{l}\text { Leaf area/ } \\
\text { plant }\left(\mathrm{m}^{2}\right)\end{array}$} & \multicolumn{2}{|c|}{$\begin{array}{c}\text { Number of } \\
\text { leaves/plants }\end{array}$} & \multicolumn{2}{|c|}{$\begin{array}{c}\text { Number of } \\
\text { branches/plants }\end{array}$} \\
\hline & \multicolumn{10}{|c|}{ Days after transplanting } \\
\hline & 30 & 60 & 30 & 60 & 30 & 60 & 30 & 60 & 30 & 60 \\
\hline & \multicolumn{10}{|c|}{ First season } \\
\hline $100 \%$ & $53.08 \mathrm{a}$ & 74.08ab & $28.4 \mathrm{ab}$ & $42.58 b$ & $2.54 \mathrm{~b}$ & $3.55 \mathrm{~b}$ & $7.66 \mathrm{a}$ & $13.17 \mathrm{a}$ & $3.91 \mathrm{ab}$ & $7.50 \mathrm{ab}$ \\
\hline $80 \%$ & $55.50 \mathrm{a}$ & $80.83 a$ & $31.58 \mathrm{a}$ & $50.83 a$ & $2.88 \mathrm{a}$ & $3.90 \mathrm{a}$ & $7.16 \mathrm{a}$ & $13.67 \mathrm{a}$ & $4.25 \mathrm{a}$ & $8.00 \mathrm{a}$ \\
\hline $60 \%$ & $49.17 \mathrm{a}$ & 73.08ab & $27.92 b$ & $48.17 \mathrm{a}$ & $1.96 \mathrm{c}$ & $2.22 \mathrm{c}$ & $6.66 \mathrm{a}$ & $9.91 b$ & $3.33 b$ & $6.75 b$ \\
\hline \multirow[t]{2}{*}{$40 \%$} & $49.58 \mathrm{a}$ & $70.92 b$ & $26.25 b$ & $33.08 \mathrm{c}$ & $1.85 \mathrm{c}$ & $2.00 \mathrm{c}$ & $6.16 \mathrm{a}$ & $7.58 \mathrm{c}$ & $3.02 \mathrm{~b}$ & $5.33 \mathrm{c}$ \\
\hline & \multicolumn{10}{|c|}{ Second season } \\
\hline $100 \%$ & $54.33 \mathrm{ab}$ & $76.33 \mathrm{ab}$ & $29.08 b$ & $44.42 b$ & $2.63 b$ & $3.09 \mathrm{~b}$ & $8.33 \mathrm{a}$ & $14.92 \mathrm{a}$ & $4.33 \mathrm{a}$ & $8.83 \mathrm{ab}$ \\
\hline $80 \%$ & $57.25 \mathrm{a}$ & $81.75 \mathrm{a}$ & $32.50 \mathrm{a}$ & $51.50 \mathrm{a}$ & $2.96 \mathrm{a}$ & $3.66 \mathrm{a}$ & $9.00 \mathrm{a}$ & $15.00 \mathrm{a}$ & $4.50 \mathrm{a}$ & $9.83 \mathrm{a}$ \\
\hline $60 \%$ & $51.33 \mathrm{a}$ & $76.08 \mathrm{ab}$ & $27.96 b$ & $9.33 \mathrm{ab}$ & $2.22 \mathrm{c}$ & $2.49 \mathrm{c}$ & $8.00 \mathrm{a}$ & $11.33 b$ & $3.50 \mathrm{a}$ & $7.91 \mathrm{~b}$ \\
\hline $40 \%$ & $51.00 \mathrm{ab}$ & $71.83 b$ & $27.00 \mathrm{c}$ & $34.28 \mathrm{c}$ & $1.89 \mathrm{~d}$ & $2.34 \mathrm{c}$ & $7.25 \mathrm{a}$ & $8.70 \mathrm{c}$ & $3.25 \mathrm{a}$ & $6.75 c$ \\
\hline
\end{tabular}

Means having the same alphabetical letter (s) are not significantly differ at 0.05 level according to Duncan's multiple range test.

Table (4): Effect of irrigation water levels on fresh weight (g) of tomato plant in 2017 and 2018 seasons.

\begin{tabular}{|c|c|c|c|c|c|c|c|c|}
\hline \multirow{3}{*}{$\begin{array}{l}\text { Irrigation } \\
\text { water levels } \\
\text { (requirements) }\end{array}$} & \multicolumn{2}{|c|}{$\overline{\operatorname{Root}}$} & \multicolumn{2}{|c|}{ Steam } & \multicolumn{2}{|c|}{ Leaves } & \multicolumn{2}{|c|}{ Total } \\
\hline & \multicolumn{8}{|c|}{ Days after transplanting } \\
\hline & 30 & 60 & 30 & 60 & 30 & 60 & 30 & 60 \\
\hline & \multicolumn{8}{|c|}{ First season } \\
\hline $100 \%$ & $42.82 \mathrm{a}$ & $65.74 \mathrm{a}$ & $30.24 b$ & $73.96 \mathrm{a}$ & $133.3 \mathrm{ab}$ & $267.7 \mathrm{a}$ & $206.36 \mathrm{a}$ & $407.4 \mathrm{a}$ \\
\hline $80 \%$ & $33.96 b$ & $50.07 \mathrm{~b}$ & $37.51 \mathrm{a}$ & $66.94 b$ & $139.1 \mathrm{a}$ & $301.1 \mathrm{a}$ & $210.57 \mathrm{a}$ & $418.11 \mathrm{a}$ \\
\hline $60 \%$ & $22.71 \mathrm{c}$ & $39.58 \mathrm{c}$ & $23.44 \mathrm{c}$ & $40.79 c$ & $123.0 \mathrm{~b}$ & $226.7 \mathrm{ab}$ & $169.15 b$ & $307.07 \mathrm{~b}$ \\
\hline \multirow[t]{2}{*}{$40 \%$} & $22.01 \mathrm{c}$ & $33.29 \mathrm{~d}$ & $21.24 \mathrm{c}$ & $33.86 \mathrm{~d}$ & $134.5 \mathrm{ab}$ & $170.1 b$ & $177.75 b$ & $237.25 \mathrm{c}$ \\
\hline & \multicolumn{8}{|c|}{ Second season } \\
\hline $100 \%$ & $43.51 \mathrm{a}$ & $67.61 \mathrm{a}$ & $32.73 b$ & $78.26 \mathrm{a}$ & $143.1 \mathrm{a}$ & $299.5 a$ & $219.34 \mathrm{a}$ & $445.37 \mathrm{a}$ \\
\hline $80 \%$ & $34.89 b$ & $52.41 \mathrm{~b}$ & $39.20 \mathrm{a}$ & $68.29 b$ & $141.8 \mathrm{a}$ & $304.7 \mathrm{a}$ & $215.89 \mathrm{a}$ & $443.4 b$ \\
\hline $60 \%$ & $23.74 \mathrm{c}$ & $41.46 \mathrm{c}$ & $25.72 \mathrm{c}$ & $41.31 \mathrm{c}$ & $125.3 \mathrm{c}$ & $228.7 b$ & $174.76 \mathrm{c}$ & $309.5 \mathrm{c}$ \\
\hline $40 \%$ & $25.89 c$ & $35.51 \mathrm{~d}$ & $23.92 \mathrm{c}$ & $35.97 \mathrm{~d}$ & $135.2 b$ & $187.6 \mathrm{c}$ & $185.01 \mathrm{~b}$ & $259.08 \mathrm{~d}$ \\
\hline
\end{tabular}

Means having the same alphabetical letter (s) are not significantly differ at 0.05 level according to Duncan's multiple range test. 
SINAI Journal of Applied Sciences (ISSN: 2314-6079), Vol. (8), Is. (1), Apr. 2019

Table (5): Effect of irrigation water level on dry weight of tomato plant in 2017 and 2018 seasons.

\begin{tabular}{|c|c|c|c|c|c|c|c|c|}
\hline \multirow{4}{*}{$\begin{array}{l}\text { Irrigation } \\
\text { water levels } \\
\text { (requirements) }\end{array}$} & \multicolumn{8}{|c|}{ Dry weight /plant (g) } \\
\hline & \multicolumn{2}{|c|}{ Root } & \multicolumn{2}{|c|}{ Steam } & \multicolumn{2}{|c|}{ leaves } & \multicolumn{2}{|c|}{ Total } \\
\hline & \multicolumn{8}{|c|}{ Days after transplanting } \\
\hline & 30 & 60 & 30 & 60 & 30 & 60 & 30 & 60 \\
\hline & \multicolumn{8}{|c|}{ First season (2017) } \\
\hline $100 \%$ & $16.26 \mathrm{a}$ & $23.51 \mathrm{a}$ & $7.38 \mathrm{a}$ & $16.89 b$ & $22.09 \mathrm{a}$ & $51.41 \mathrm{a}$ & $46.09 \mathrm{a}$ & $91.81 \mathrm{a}$ \\
\hline $80 \%$ & $12.96 \mathrm{a}$ & $18.70 \mathrm{~b}$ & $7.88 \mathrm{a}$ & $17.75 \mathrm{a}$ & $23.65 \mathrm{a}$ & $53.27 \mathrm{a}$ & $44.49 \mathrm{a}$ & $89.72 \mathrm{a}$ \\
\hline $60 \%$ & $9.48 b$ & $11.18 \mathrm{c}$ & $6.76 \mathrm{a}$ & $10.94 \mathrm{c}$ & $18.98 \mathrm{~b}$ & $26.99 b$ & $35.22 b$ & $49.11 b$ \\
\hline \multirow[t]{2}{*}{$40 \%$} & $7.70 \mathrm{~b}$ & $9.04 \mathrm{~d}$ & $6.61 \mathrm{a}$ & $8.69 \mathrm{~d}$ & $13.13 \mathrm{c}$ & $18.08 \mathrm{c}$ & $27.44 \mathrm{c}$ & $35.81 \mathrm{c}$ \\
\hline & \multicolumn{8}{|c|}{ Second season (2018) } \\
\hline $100 \%$ & $17.38 \mathrm{a}$ & $25.92 \mathrm{a}$ & $8.44 a$ & $18.43 b$ & $23.48 \mathrm{a}$ & $56.72 \mathrm{a}$ & $49.3 \mathrm{a}$ & $101.07 \mathrm{a}$ \\
\hline $80 \%$ & $14.52 \mathrm{a}$ & $19.83 b$ & $9.11 \mathrm{a}$ & $19.60 \mathrm{a}$ & $24.69 \mathrm{a}$ & $55.25 \mathrm{a}$ & $48.32 \mathrm{a}$ & $94.68 b$ \\
\hline $60 \%$ & $10.50 \mathrm{~b}$ & $12.51 \mathrm{c}$ & $7.73 \mathrm{ab}$ & $12.12 \mathrm{c}$ & $20.14 \mathrm{c}$ & $27.13 \mathrm{c}$ & $38.37 \mathrm{c}$ & $51.76 \mathrm{c}$ \\
\hline $40 \%$ & $8.80 \mathrm{~b}$ & $10.18 \mathrm{c}$ & $6.73 b$ & $9.70 \mathrm{~d}$ & $14.55 \mathrm{~d}$ & $19.18 \mathrm{~d}$ & $30.08 \mathrm{~d}$ & $39.06 \mathrm{~d}$ \\
\hline
\end{tabular}

Means having the same alphabetical letter (s) are not significantly differ at 0.05 level according to Duncan's multiple range test.

Table (6): Effect of irrigation water level on chlorophyll and carotenoids content of tomato leaves in 2017 and 2018 seasons.

\begin{tabular}{|c|c|c|c|c|c|c|}
\hline \multirow{3}{*}{ Parameter } & \multicolumn{2}{|c|}{$\begin{array}{c}\text { Chlorophyll a } \\
\left(\mathrm{mgg}^{-1} \mathrm{FW}\right)\end{array}$} & \multicolumn{2}{|c|}{$\begin{array}{c}\text { Chlorophyll b } \\
\left(\mathrm{mgg}^{-1} \mathrm{FW}\right)\end{array}$} & \multicolumn{2}{|c|}{$\begin{array}{c}\text { Carotenoids } \\
\left(\mathrm{mgg}^{-1} \mathrm{FW}\right)\end{array}$} \\
\hline & \multicolumn{6}{|c|}{ Days after transplanting } \\
\hline & 30 & 60 & 30 & 60 & 30 & 60 \\
\hline & \multicolumn{6}{|c|}{ First season (2017) } \\
\hline $100 \%$ & $3.125 \mathrm{a}$ & $3.905 \mathrm{ab}$ & $1.809 \mathrm{a}$ & $1.947 b$ & $2.193 \mathrm{a}$ & $2.642 \mathrm{~b}$ \\
\hline $80 \%$ & $3.174 \mathrm{a}$ & $4.305 \mathrm{a}$ & $1.769 \mathrm{a}$ & $2.207 \mathrm{a}$ & $2.203 \mathrm{a}$ & $2.892 \mathrm{a}$ \\
\hline $60 \%$ & $3.115 \mathrm{a}$ & $3.506 \mathrm{bc}$ & $1.657 \mathrm{a}$ & $1.781 \mathrm{~b}$ & $2.090 \mathrm{a}$ & $2.384 \mathrm{c}$ \\
\hline \multirow[t]{2}{*}{$40 \%$} & $2.537 \mathrm{~b}$ & $3.232 \mathrm{c}$ & $1.316 \mathrm{a}$ & $1.697 \mathrm{~b}$ & $1.689 \mathrm{~b}$ & $2.208 \mathrm{c}$ \\
\hline & \multicolumn{6}{|c|}{ Second season (2018) } \\
\hline $100 \%$ & $3.093 \mathrm{a}$ & $4.184 \mathrm{a}$ & $1.753 \mathrm{a}$ & $2.04 \mathrm{~b}$ & $2.214 \mathrm{a}$ & $2.682 \mathrm{a}$ \\
\hline $80 \%$ & $2.980 \mathrm{a}$ & $4.216 \mathrm{a}$ & $1.762 \mathrm{a}$ & $2.213 \mathrm{a}$ & $2.206 \mathrm{a}$ & $2.830 \mathrm{a}$ \\
\hline $60 \%$ & $2.995 \mathrm{a}$ & $3.715 b$ & $1.765 \mathrm{a}$ & $1.879 b c$ & $2.224 \mathrm{a}$ & $2.453 \mathrm{~b}$ \\
\hline $40 \%$ & $2.623 \mathrm{a}$ & $3.207 \mathrm{c}$ & $1.577 \mathrm{~b}$ & $1.783 \mathrm{c}$ & $1.903 \mathrm{~b}$ & $2.289 \mathrm{~b}$ \\
\hline
\end{tabular}

Means having the same alphabetical letter (s) are not significantly differ at 0.05 level according to Duncan's multiple range test. 
Table (7): Effect of irrigation water level on marketable yield of tomato plants in 2017 and 2018 seasons.

\begin{tabular}{|c|c|c|c|c|c|c|c|}
\hline \multirow{2}{*}{ 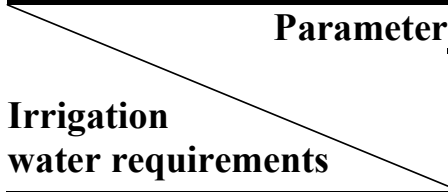 } & \multicolumn{3}{|c|}{ Grade A fruits } & \multicolumn{2}{|c|}{ Grade B fruits } & \multicolumn{2}{|c|}{ Total Yield } \\
\hline & $\begin{array}{l}\text { Mean fruit } \\
\text { weight } \\
\text { (g) }\end{array}$ & $\begin{array}{c}\text { No. } \\
\text { fruits } \\
\left(\mathbf{m}^{2}\right)\end{array}$ & $\begin{array}{c}\text { Weight of } \\
\text { fruits } \\
\left(\text { ton }_{\text {fad }}{ }^{-1}\right)\end{array}$ & $\begin{array}{c}\text { No. } \\
\text { fruits } \\
\left(\mathbf{m}^{2}\right)\end{array}$ & $\begin{array}{c}\text { Weight of } \\
\text { fruits } \\
\left(\text { ton } \text { fad }^{-1}\right)\end{array}$ & $\begin{array}{l}\text { No. } \\
\text { fruits } \\
\left(\mathbf{m}^{2}\right)\end{array}$ & $\begin{array}{c}\text { Weight of } \\
\text { fruits } \\
\left(\text { ton } \text { fad }^{-1}\right)\end{array}$ \\
\hline & \multicolumn{7}{|c|}{ First season (2017) } \\
\hline $100 \%$ & $92.63 a$ & $31.58 \mathrm{~b}$ & $12.91 b$ & $3.693 b$ & $12.00 \mathrm{a}$ & $43.58 \mathrm{c}$ & $16.61 b$ \\
\hline $80 \%$ & $71.59 b$ & $44.00 \mathrm{a}$ & $14.09 \mathrm{a}$ & $4.442 \mathrm{ab}$ & $17.42 \mathrm{a}$ & $61.42 \mathrm{a}$ & $18.53 \mathrm{a}$ \\
\hline $60 \%$ & $70.24 b$ & $31.50 \mathrm{~b}$ & $10.67 \mathrm{c}$ & $4.744 \mathrm{ab}$ & $20.67 \mathrm{a}$ & $52.17 \mathrm{~b}$ & $15.41 \mathrm{c}$ \\
\hline \multirow[t]{2}{*}{$40 \%$} & $71.40 \mathrm{~b}$ & $30.25 b$ & $9.361 \mathrm{~d}$ & $5.654 a$ & $19.92 \mathrm{a}$ & $50.17 \mathrm{~b}$ & $15.05 \mathrm{c}$ \\
\hline & \multicolumn{7}{|c|}{ Second Season (2018) } \\
\hline $100 \%$ & $91.85 \mathrm{a}$ & $33.56 \mathrm{~b}$ & $13.45 b$ & $3.485 b$ & $12.00 \mathrm{a}$ & $44.66 \mathrm{c}$ & $17.32 b$ \\
\hline $80 \%$ & $70.75 b$ & $45.63 \mathrm{a}$ & $14.66 \mathrm{a}$ & $4.563 \mathrm{ab}$ & $17.42 \mathrm{a}$ & $62.45 \mathrm{a}$ & $19.41 \mathrm{a}$ \\
\hline $60 \%$ & $71.66 \mathrm{~b}$ & $33.51 b$ & $11.36 \mathrm{c}$ & $4.522 \mathrm{ab}$ & $20.67 \mathrm{a}$ & $45.20 \mathrm{~b}$ & $16.32 \mathrm{c}$ \\
\hline $40 \%$ & $71.42 b$ & $33.35 b$ & $10.61 d$ & $5.632 \mathrm{a}$ & $19.92 \mathrm{a}$ & $53.23 b$ & $16.10 \mathrm{c}$ \\
\hline
\end{tabular}

Means having the same alphabetical letter (s) are not significantly differ at 0.05 level according to Duncan's multiple range test.

Table (8): Effect of irrigation water level on fruit un-marketable yield of tomato in 2017 and 2018 seasons.

\begin{tabular}{|c|c|c|c|c|}
\hline \multirow{2}{*}{$\begin{array}{l}\text { Irrigation } \\
\text { water requirements }\end{array}$} & $\begin{array}{c}\text { Number } \\
\text { of fruits } / \mathbf{m}^{2}\end{array}$ & $\begin{array}{l}\text { Yield/fad. } \\
\text { (ton) }\end{array}$ & $\begin{array}{c}\text { Number } \\
\text { of fruits } / \mathbf{m}^{2}\end{array}$ & $\begin{array}{l}\text { Yield/fad. } \\
\text { (ton) }\end{array}$ \\
\hline & \multicolumn{2}{|c|}{ First Season (2017) } & \multicolumn{2}{|c|}{ Second Season (2018) } \\
\hline$\overline{100 \%}$ & $9.672 b$ & $1.262 \mathrm{~b}$ & $9.650 \mathrm{~b}$ & $1.283 \mathrm{~b}$ \\
\hline $80 \%$ & $9.904 \mathrm{~b}$ & $1.233 \mathrm{~b}$ & $9.904 \mathrm{~b}$ & $1.264 \mathrm{~b}$ \\
\hline $60 \%$ & $10.97 \mathrm{a}$ & $1.384 \mathrm{a}$ & $10.85 \mathrm{a}$ & $1.412 \mathrm{a}$ \\
\hline $40 \%$ & $11.07 \mathrm{a}$ & $1.202 \mathrm{~b}$ & $11.11 \mathrm{a}$ & $1.227 \mathrm{~b}$ \\
\hline
\end{tabular}

Means having the same alphabetical letter (s) are not significantly differ at 0.05 level according to Duncan's multiple range test. 
SINAI Journal of Applied Sciences (ISSN: 2314-6079), Vol. (8), Is. (1), Apr. 2019

Table (9): Effect of irrigation water levels on quality of tomato fruits in 2017 and 2018 seasons.

\begin{tabular}{|c|c|c|c|c|c|c|c|}
\hline$\overbrace{\text { Irrigation levels }}^{\text {Parameter }}$ & $\begin{array}{c}\text { Fruit } \\
\text { Length } \\
\text { (cm) }\end{array}$ & $\begin{array}{c}\text { fruit } \\
\text { diameter } \\
(\mathrm{cm})\end{array}$ & $\begin{array}{l}\text { Fruit } \\
\text { shape } \\
\text { (L/D) } \\
\end{array}$ & $\begin{array}{c}\text { Pericarp } \\
\text { thickness } \\
(\mathbf{m m}) \\
\end{array}$ & $\begin{array}{c}\text { Fruit } \\
\text { TSS } \\
(\%) \\
\end{array}$ & $\begin{array}{c}\text { Vitamin. } \\
\mathrm{C} \\
(\mathrm{mg} / \mathbf{1 0 0} \mathrm{g})\end{array}$ & $\begin{array}{c}\mathrm{pH} \\
\text { of } \\
\text { fruits }\end{array}$ \\
\hline & \multicolumn{7}{|c|}{ First season (2017) } \\
\hline $100 \%$ & $49.38 \mathrm{ab}$ & $55.29 \mathrm{a}$ & $0.8983 a$ & $2.375 \mathrm{a}$ & $5.417 \mathrm{c}$ & $19.83 \mathrm{ab}$ & $4.525 b$ \\
\hline $80 \%$ & $52.76 \mathrm{a}$ & $53.94 \mathrm{a}$ & $0.9858 \mathrm{a}$ & $1.942 \mathrm{ab}$ & $5.583 b c$ & $20.83 a$ & $4.642 \mathrm{a}$ \\
\hline $60 \%$ & $48.07 \mathrm{~b}$ & $49.84 \mathrm{a}$ & $0.9775 \mathrm{a}$ & $1.842 \mathrm{ab}$ & $6.833 \mathrm{ab}$ & $18.50 \mathrm{bc}$ & $4.550 \mathrm{ab}$ \\
\hline \multirow[t]{2}{*}{$40 \%$} & $47.79 b$ & $49.04 \mathrm{a}$ & $0.9842 \mathrm{a}$ & $1.517 \mathrm{~b}$ & $7.083 \mathrm{a}$ & $17.33 \mathrm{c}$ & $4.500 \mathrm{~b}$ \\
\hline & \multicolumn{7}{|c|}{ Second season (2018) } \\
\hline $100 \%$ & $48.56 b$ & $52.29 \mathrm{a}$ & $0.9167 \mathrm{a}$ & $2.417 \mathrm{a}$ & $5.583 b$ & $18.92 b$ & $4.533 \mathrm{a}$ \\
\hline $80 \%$ & $52.18 \mathrm{a}$ & $51.94 \mathrm{a}$ & $0.9958 \mathrm{a}$ & $2.058 \mathrm{a}$ & $5.667 b$ & $20.92 \mathrm{a}$ & $4.625 \mathrm{a}$ \\
\hline $60 \%$ & $48.36 b$ & $50.84 \mathrm{a}$ & $0.9558 \mathrm{a}$ & $1.975 \mathrm{a}$ & $6.583 \mathrm{ab}$ & $17.75 \mathrm{bc}$ & $4.583 \mathrm{a}$ \\
\hline $40 \%$ & $46.74 b$ & $50.04 \mathrm{a}$ & $0.9558 \mathrm{a}$ & $1.442 b$ & $7.083 \mathrm{a}$ & $17.000 \mathrm{c}$ & $4.517 \mathrm{a}$ \\
\hline
\end{tabular}

Means having the same alphabetical letter (s) are not significantly differ at 0.05 level according to Duncan's multiple range test.

\section{REFERENCES}

Allakhverdiev, S.I.; Sakamoto, A.; Nishiyama, Y.; Inaba, M. and Murata, N. (2000). Ionic and osmotic effects of $\mathrm{NaCl}$ induced inactivation of photosystems I and II in Synechococcus sp. Plant Physiol., 123: 1047-1056.

Al-Omran, M.; Al-Harbi, A.R.; AbdAllah, A.M; Nadeem, M. and Al-Eater A. (2010). Impact of irrigation water quality, irrigation systems, irrigation rates and soil amendments on tomato production in sandy calcareous soil. Turk J. Agric., 34: 59-73.

Berihun, B. (2011). Effect of mulching and amount of water on the yield of tomato under drip irrigation. J. Hort. and Forestry, 3 (7): 200-206.

Biswas, S.; Akanda, A.R.; Rahman, M.S. and Hossain, M.A. (2015). Effect of drip irrigation and mulching on yield, water-use efficiency and economics of tomato. Plant Soil Environ, 61 (3): 97102.

Duncan, R.L. (1955). Multiple Range and Multiple F test. Biometrics, 11: 1-42.

Ezekiel, O. (2013). Vegetative growth and yield of tomato as affected by water regime and mulching. PAT December, 9 (2): 43-53 ISSN: 0794-5213.

Ismail, M.; Ozawa, K. and Khondaker, A. (2007). Effect of irrigation frequency and timing on tomato yield, soil water dynamics and water use efficiency under drip irrigation. Eleventh Int. Water Technol. Conf., IWTC11, Sharm ElSheikh, Egypt.

Jackson, M.L. (1967). Soil Chemical Analysis. Principle Hall, Inc., Engle Wood Chiff, N.J.

Koca, M.; Bor, M.; Ozdemir, F. and Turkan, I. (2007). The effect of salt stress on lipid peroxidation, antioxidative enzymes and proline content of sesame 
cultivars. Environ. Exp. Bot., 60: 344 351.

Piper, C.S. (1947). Soil and Plant Analysis. The University of Adelaide (Australia), 59-74.

Ragab, M.E.; Sawan, O.M.; Hassan, Z.F.; El-Bassiony, A.M. and El-Sawy, S.M. (2018). Increasing the productivity of tomato plants grown in sandy soil under deficit irrigation water conditions. Res. and Rev., J. Agric. and Apl. Sci., 7: 2.
Richard, L.A. (1954). Diagnosis and Improvement of Saline Alkaline soils. U. S. D. A. Handbook No. 60.

Sibomana, C.I.; Aguyo, J.N. and Opiyo, A.M. (2013). Water stress affects growth and yield of container grown tomato (lycopersicon esculentum mill.) plants. GJBB, 2 (4): 461-466.

Snedecor, G.W. and Cochran, W.G. (1980). Statistical Methods $7^{\text {th }}$ Ed. Iowa State Univ. Press. Ames. Iowa, USA.

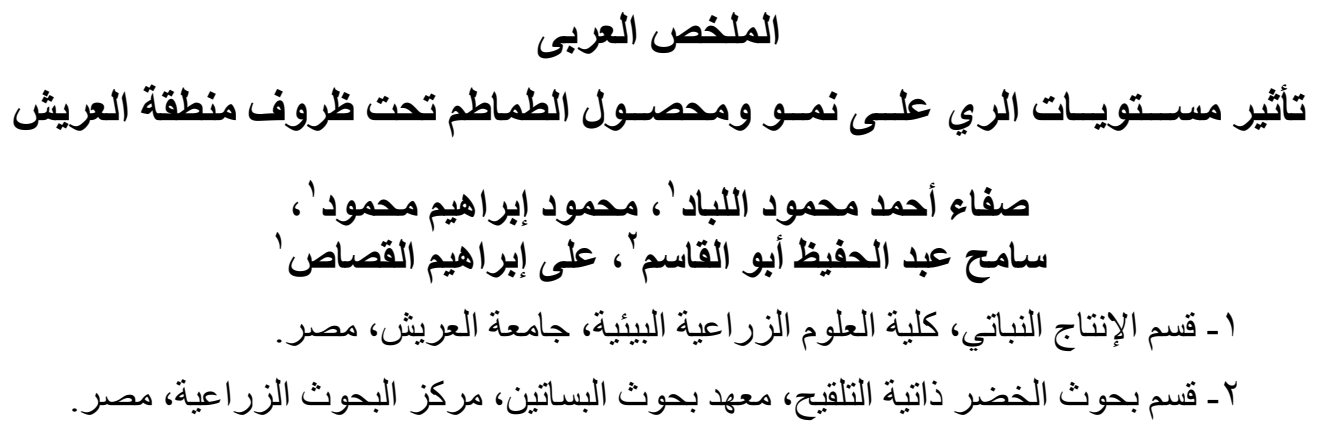

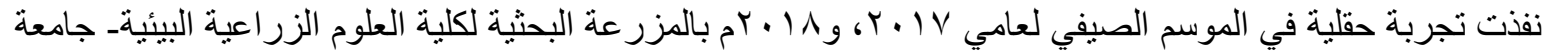

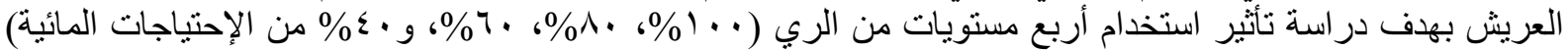

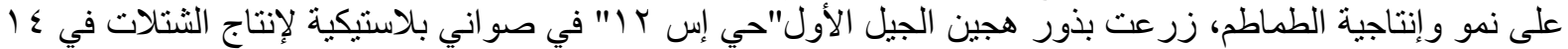

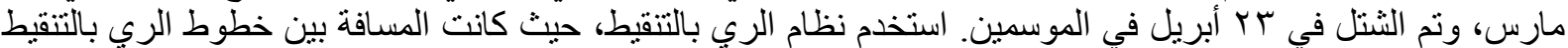

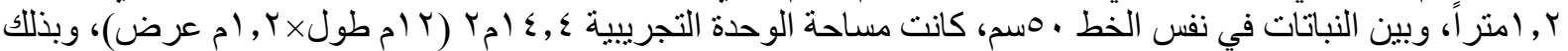

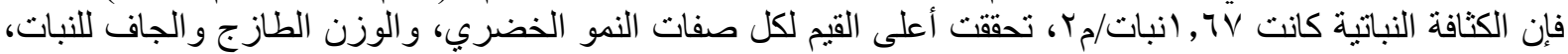

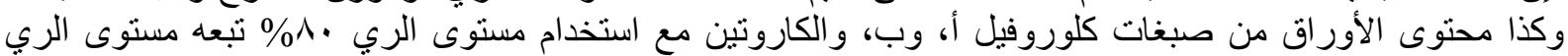

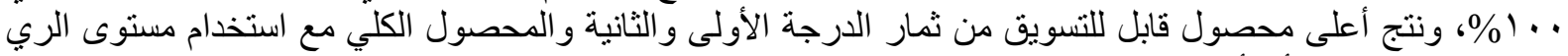

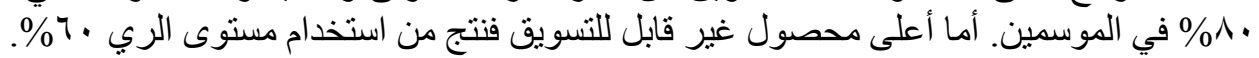
الكلمات الإسترشادية: الرى، محصول الطماطم، ، مستويات، المياه، كفاءة. 